\title{
СОСТАВ РЫБЬЕГО ЖИРА, СОЕВОГО И ЛЬНЯНОГО МАСЛА И ИХ ВЛИЯНИЕ В ФОРМИРОВАНИИ КОСТНОЙ ТКАНИ
}

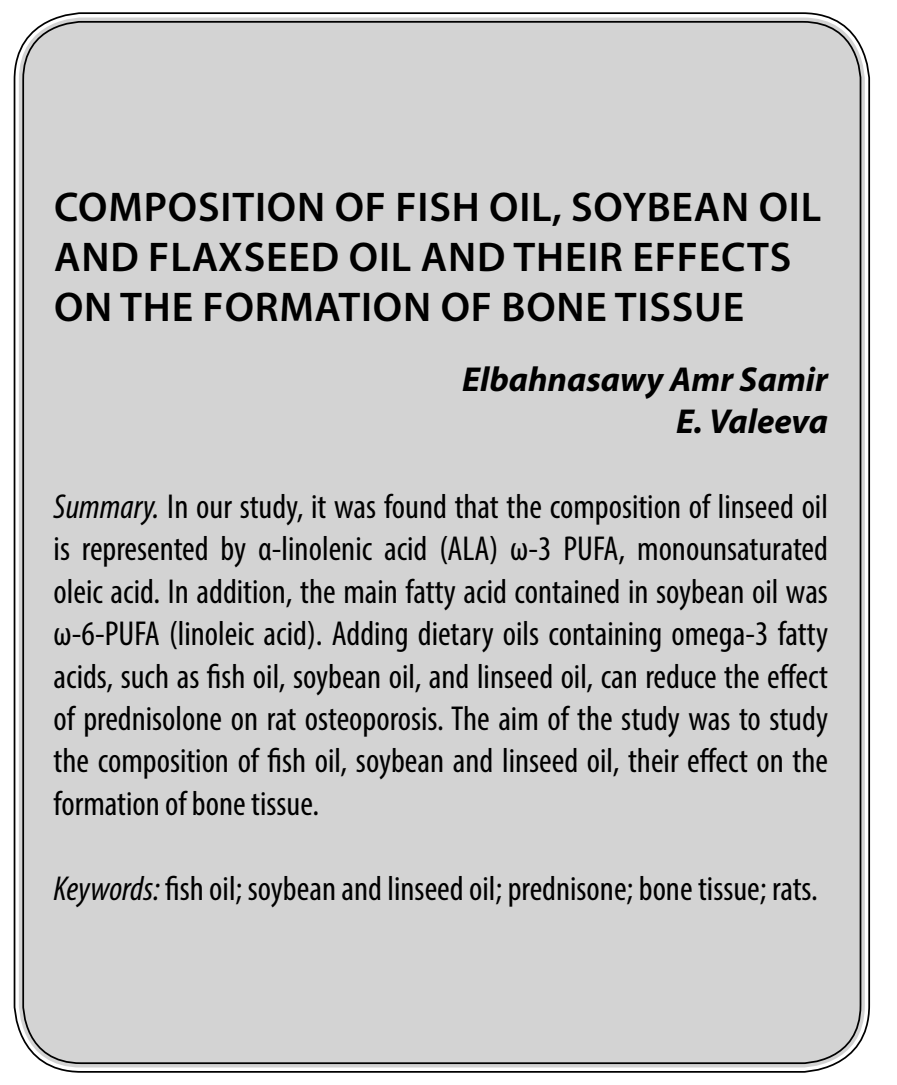

\section{Ввехение}

O вощная соя (Glycine max (L.) Merr.), травянистое растение из семейства Fabaceae (бобовые). Это самая важная бобовая культура в мире и наиболее широко распространенная масличная культура, выращиваемая в различных климатических условиях во всем мире.

Существует несколько групп питательных веществ в соевых бобах, которые в настоящее время исследуются на предмет полезного воздействия на здоровье, такие как флавоноиды и изофлавоноиды, фенольные кислоты, фитоалексины, фитостеролы, белки и пептиды и сапонины. El Wakf et al., [1] обнаружено, что прием пищи, дополненной соевым маслом, может быть полезен для защиты от потери костной массы, вызванного дефицитом эстрогены в статусе овариэктомии, что видно из улучшения минеральной плотности костей.

Семя льна (Linum usitatissimum L.) является членом семейства Linaceae. Льняное масло широко потребля-

\author{
Элбахнасави Амр Самир \\ Аспирант, Казанский (Приволжский) федеральный \\ университет, Россия, г. Казань \\ amrsamir84@yahoo.com \\ Валеева Эмилия Рамзиевна \\ Д.м.н., профессор, Казанский (Приволжский) \\ федеральный университет, Россия, г. Казань \\ val_med@mail.ru
}

Аннотация. В нашем исследовании установлено, что состав льняного масла представлен а-линоленовой кислотой (ALA) $\omega$-3 ПНЖK, мононенасыщенной олеиновой кислотой. Кроме того, основной жирной кислоты, содержащейся

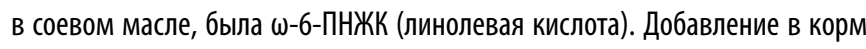
диетических масел, содержащих олиненасыщенные жирные кислоты омега-3, таких как рыбий жир, соевое масло и льняное масло, может снизить эффект преднизолона в развития остеопороза у крыс. Целью исследования явилось изучение состава рыбьего жира, соевого и льняного масла, их влияние на формировании костной ткани.

Ключевые слова: рыбий жир; соевое и льняное масло; преднизолон; костная ткань; крысы.

ется и стало объектом клинических исследований благодаря его функциональным свойствам. Льняное масло содержит большое количество биологически активных соединений, которые оказывают гиполипидемическое и антиоксидантное действие [2].

На рыбий жир приходится около 2\% мирового потребления жиров и масел. Высокий уровень питательных ценных длинноцепочечных полиненасыщенных жирных кислот (ПНЖК), в основном эйкозапентаеновой кислоты (EPA) и докозагексаеновой кислоты (DHA), наряду с их физико-химическими свойствами, делает рыбные липиды уникальными и перспективным экономически ценным продуктом. Хотя текущая ситуация с производством рыбьего жира стабильна, будущие прогнозы показывают, что имеющиеся дикие морские ресурсы становятся все более ограниченными, в то время как спрос на использование рыбьего жира продолжает расти во многих областях, таких как кормление животных, функциональные продукты питания и напитки, диетические добавки и фармацевтические препараты [3]. Cao et al., [4] сообщили, что увеличение содержания рыбьего жира в рационе 


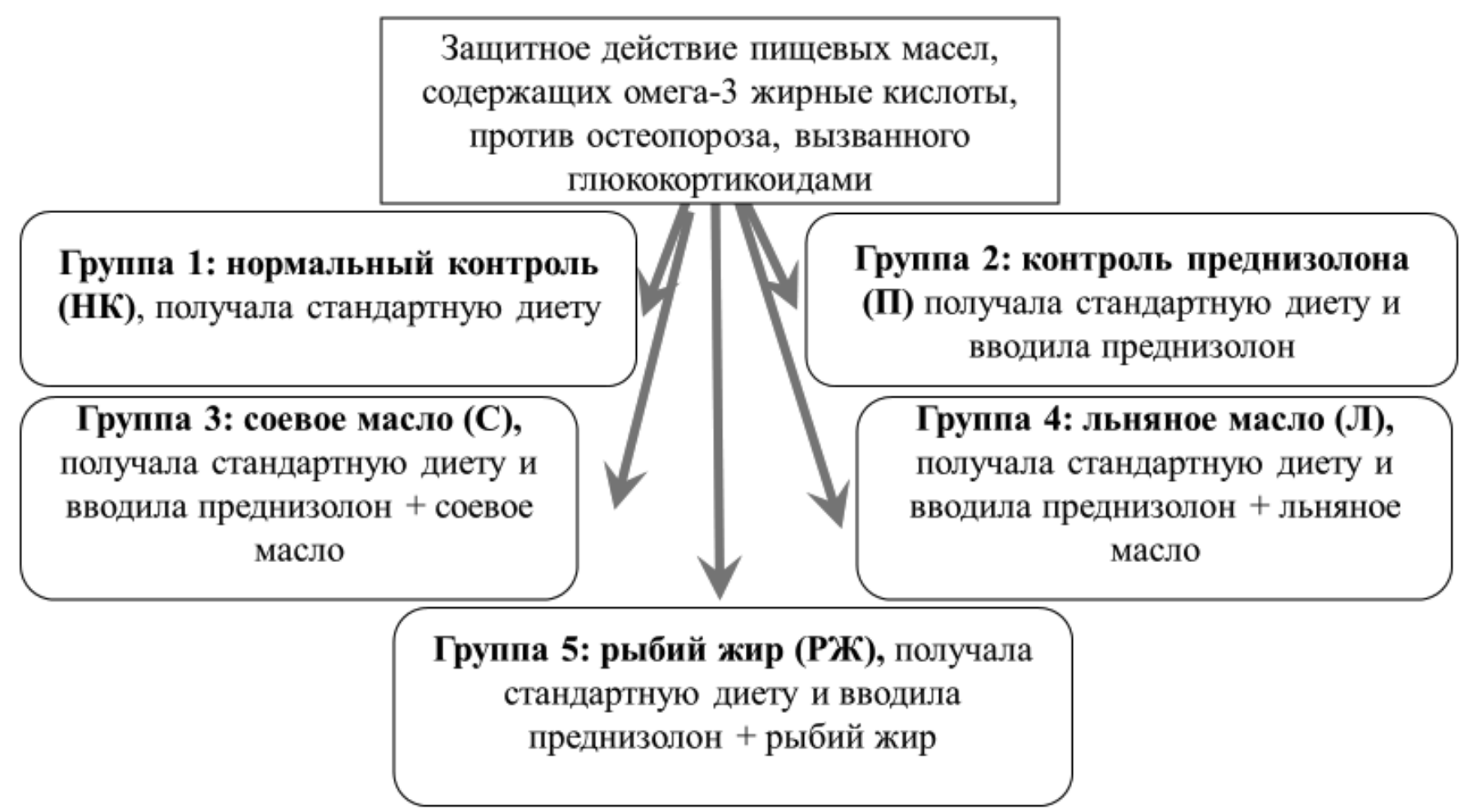

Рис. 1. Эксперимент с преднизолоном

снижает ожирение, воспаление жировой ткани и резорбцию кости и увеличивает костную массу у мышей.

Целью исследования явилось изучение состава рыбьего жира, соевого и льняного масла, их влияние на формировании костной ткани.

\section{1. Материалы и мето $\Delta \mathrm{b}$}

Рыбий жир (из печени трески) был получен от Тульского фармацевтического завода, г.Тула, Российская Федерация. Соевые и льняные масла были приобретены в Научно-исследовательском институте пищевых технологий, Сельскохозяйственный исследовательский центр, Гиза, Египет. Образцы масла хранили при - $20^{\circ} \mathrm{C}$ в темных стеклянных бутылках до использования.

Изучение и анализ жирных кислот (ЖК) масел. Образцы масла были этерифицированы и метилированы в соответствии с официальным методом AOCS Ce 2-66 [5]. Метиловые эфиры ЖК были определены методом газовой хроматографии с использованием прибора фирмы Perkin Elmer Auto System XL, поставляемой с детектором ионизации пламени. Соединения разделяли на капиллярной колонке из плавленого кварца DB-Wax (внутренний диаметр 60 × 0,32 мм, толщина пленки 0,20 мкм). Температуру печи вначале поддерживали на уровне $50{ }^{\circ} \mathrm{C}$ в течение 5 минут, затем запрограммировали на повышение от 50 до $220^{\circ} \mathrm{C}$ со скоростью $4{ }^{\circ} \mathrm{C} /$ мин. Скорости потока газа-носителя - гелия соответствовала 1,1 мл / мин. Температуры инжектора и детектора составляли 220 и $250{ }^{\circ} \mathrm{C}$ соответственно. FA были идентифицированы путем сравнения времен удерживания чистых стандартных метиловых эфиров FA с отдельными компонентами образцов, которые были количественно определены с помощью нормализации площади (\%) [6]. В качестве стандарта использовали смесь, состоящую из 37 метиловых эфиров ЖК (Supelco, Sigma-Aldrich Co. LLC, Германия) с чистотой от 99,1 до $99,9 \%$.

Эксперимент на крысах животные были разделены на 5 групп (10 крыс на группу) следующим образом (Рис. 1): фактор некроза опухоли-альфа (ФНО-а). определяли по методу (ELISA) с помощью RayBio ${ }^{\circledast}$ Rat ФHO-a (RayBiotech, Inc., Норкросс, Джорджия, США). Малонового диальдегида (МДА), определяли по методу Draper and Hadley [7], основанному на реакции MDA с тиобарбитуровой кислотой (ТВА).

Гистопатологическое исследование включало в себя следующее: бедренные кости помещали в 10\% формалин в физиологическом растворе на 48 часов, затем начинали декальцинацию этилендиаминтетрауксусной кислотой (EDITA) 10\% через 7-7,4 ч в течение 
Таблица 1. Жирно-кислотный профиль рыбьего жира, льняного масла и соевого масла

\begin{tabular}{|c|c|c|c|}
\hline \multirow{2}{*}{ Жирные кислоты } & \multicolumn{3}{|c|}{$\begin{array}{l}\text { Концентрация (\%) от общего количества } \\
\text { жирных кислот }\end{array}$} \\
\hline & Рыбий жир & $\begin{array}{l}\text { Льняное } \\
\text { масло }\end{array}$ & Соевое масло \\
\hline \multicolumn{4}{|l|}{ Насыщенные жирные кислоты (НЖК) } \\
\hline Миристический С14:0 & 5,19 & $\mathrm{HO}$ & $\mathrm{HO}$ \\
\hline Пальмитиновая кислота С16: 0 & 8,17 & 8,80 & 12,19 \\
\hline Стеариновая кислота С18: 0 & 2,05 & 5,79 & 4,22 \\
\hline Арахидовая кислота С20: 0 & $\mathrm{HO}$ & 0,26 & 0,37 \\
\hline Бегеновая кислота, С22: 0 & $\mathrm{HO}$ & $\mathrm{HO}$ & 0,13 \\
\hline Всего НЖК & 15,41 & 14,85 & 16,91 \\
\hline \multicolumn{4}{|l|}{ Мононенасыщенные жирные кислоты (МНЖК) } \\
\hline Пальмитолеиновая кислота, C16: 1n7 & 6,39 & $\mathrm{HO}$ & $\mathrm{HO}$ \\
\hline Олеиновая кислота, C18: 1n9 & 12,21 & 21,40 & 24,35 \\
\hline Вакценовая кислота, С18: 1n7 & 4,14 & $\mathrm{HO}$ & $\mathrm{HO}$ \\
\hline Эйкозеновая кислота С20: 1n9 & 8,35 & $\mathrm{HO}$ & $\mathrm{HO}$ \\
\hline Цетолеиновая кислота, С22: 1n11 & 5,19 & $\mathrm{HO}$ & $\mathrm{HO}$ \\
\hline Всего МНЖК & 36,28 & 21,40 & 24,35 \\
\hline \multicolumn{4}{|l|}{ Полиненасыщенные жирные кислоты (ПНЖК) } \\
\hline Линолевая кислота, С18: 2n6 & 1,5 & 22,47 & 53,58 \\
\hline a-Линоленовая кислота (ALA) C18: 3n3 & 0,74 & 40,29 & 4,67 \\
\hline Стеаридоновая кислота С 18: 4n3 & 3,6 & $\mathrm{HO}$ & $\mathrm{HO}$ \\
\hline Арахидоновая кислота, С20: 4n6 & 0,25 & $\mathrm{HO}$ & $\mathrm{HO}$ \\
\hline Эйкозапентаеновая кислота (ЕРА) С20: 5n3 & 19,12 & $\mathrm{HO}$ & $\mathrm{HO}$ \\
\hline Докозапентаеновая кислота, (DPA) C22: 5n3 & 1,9 & $\mathrm{HO}$ & $\mathrm{HO}$ \\
\hline Докозагексаеновая кислота (DHA) C22: 6n3 & 21,08 & $\mathrm{HO}$ & $\mathrm{HO}$ \\
\hline Всего $\omega-6$ полиненасыщенных жирных кислот & 1,75 & 22,47 & 53,58 \\
\hline Всего $\omega-3$ полиненасыщенных жирных кислот & 46,44 & 40,29 & 4,67 \\
\hline Всего ПНЖК & 48,19 & 62,76 & 58,25 \\
\hline
\end{tabular}

НО (не обнаружено).

4 недель, Очищенные фиксированные ткани помещали в парафин. образуя блоки из твердого парафина с тканями в его центрах, каждый блок из твердого парафина разрезали на тонкие срезы (толщиной 6 микрометров). Предметные стекла окрашивали гематоксилином и эозином (Н \& E). Окрашенные срезы исследовали гистологически и фотографировали. Изображения анализировали с помощью Optima (Media Cybernetics, 1998 г., версия 6.21.19) и с помощью светового микроскопа [8].

Данные были статистически проанализированы в операционной системе Windows 10 с использованием стандартной прикладной программы «Microsoft Word», статистической программы CoStat Version 6.451 (CoHort Software, США), электронных таблицах «Excel 2016», с использованием пакета ATTESTAT.

\section{2. Результаты}

\section{Анализ и состав рыбьего жира, соевого масла, льняного масла}

Профиль жирных кислот рыбьего, льняного и соевого масел представлен в таблице 1. Процентное содержание общих насыщенных жирных кислот (SFA) в соевом масле было немного выше, чем у рыбьего жиар и льняного масла, основной насыщенной жирной кислотой, обнаруженной в трех маслах, была пальмитиновая кислота C16: 0. Можно также отметить, что рыбий жир содержал множество мононенасыщенных жирных кислот (MUFA), которые показали наибольшее значение по сравнению с соевым и льняным маслами, которые имели высокое содержание олеиновой кислоты C18: 1n9. Рыбий жир содержал высокие уровни длинноцепочечных $\omega$-3 поли- 


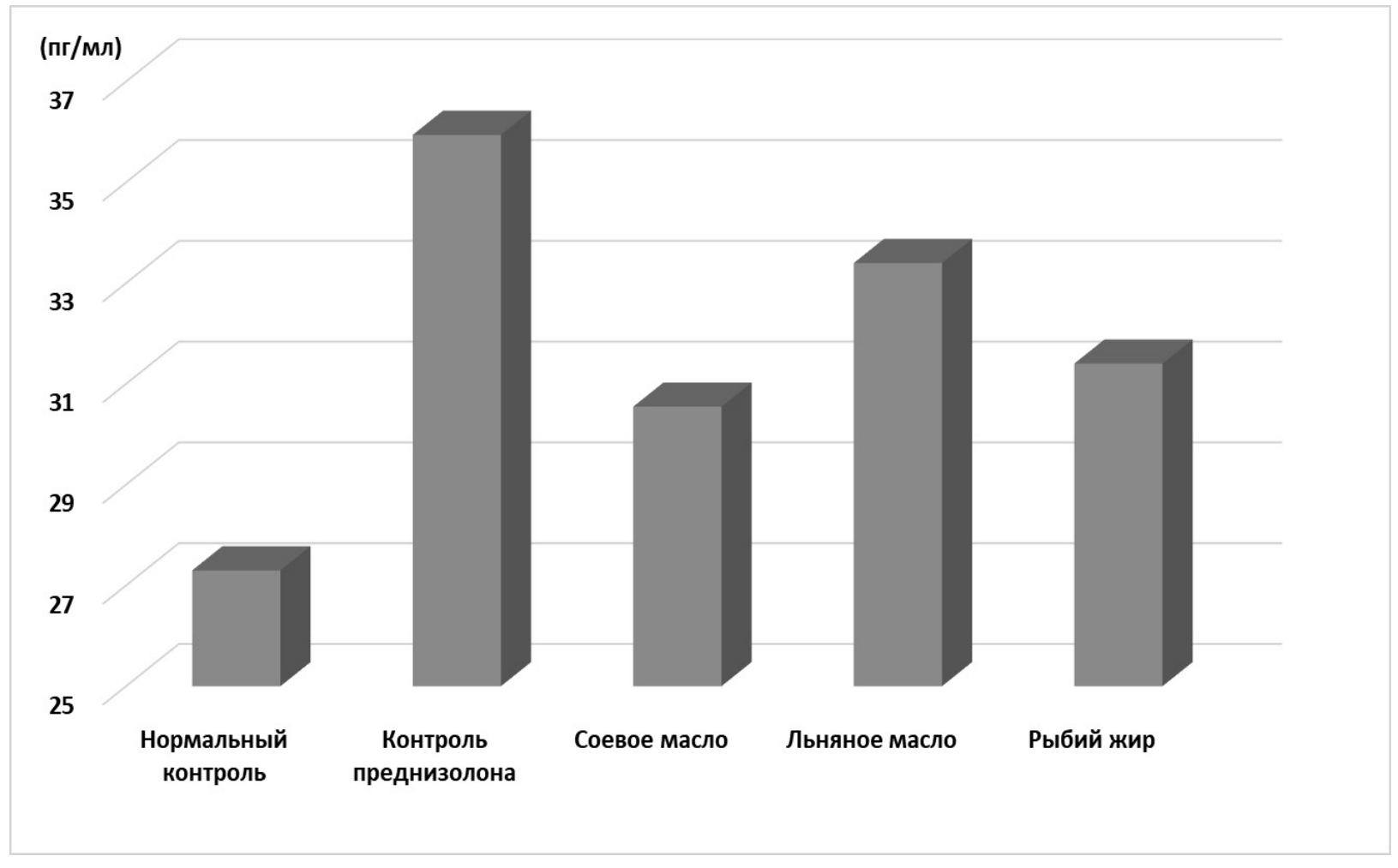

Рис. 2.Уровни ФНО-а

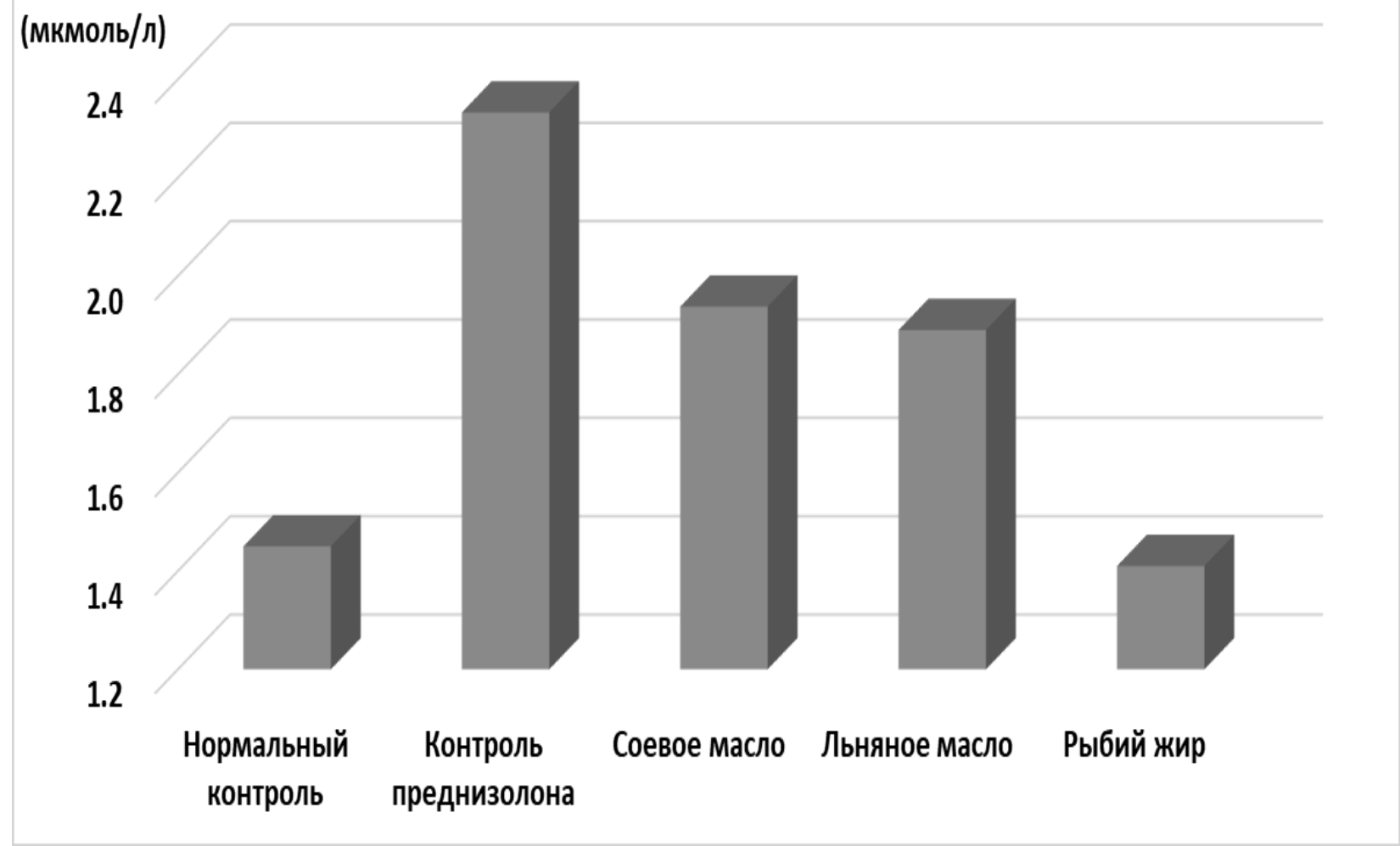

Рис. 3. Уровни МДА 


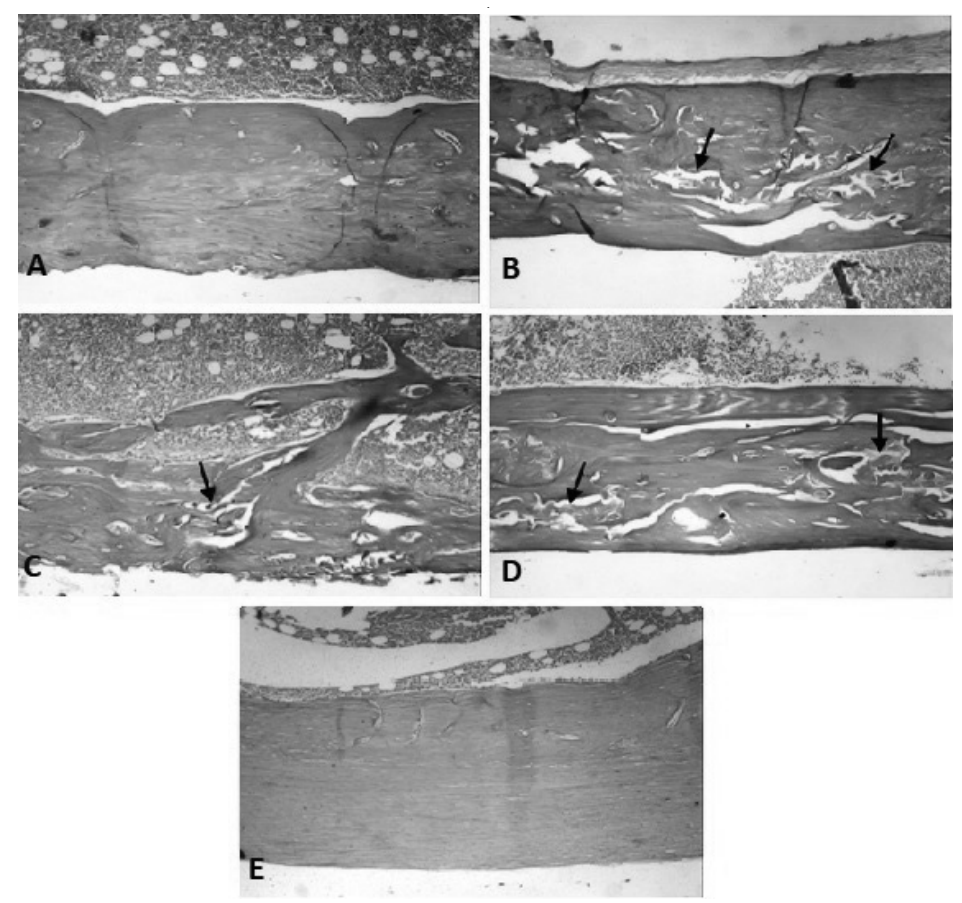

Рис. 4.(А) Микрофотография кости крысы из контрольной группы без гистопатологических изменений, нормальной толщины кортикальной кости и остеоцита; (В) микрофотография кости крысы группы с преднизолоном, показывающая несколько полостей резорбции в матрице, аномальный остеоцит, тонкую кортикальную кость с наличием трещин; (C) микрофотография кости крысы из группы соевого масла, показывающая небольшое количество трещин в кортикальной кости; (D) микрофотография кости крысы из группы льняного масла, показывающая очаговый некроз с небольшим количеством трещин в кортикальной кости; (Е) Микрофотография кости крысы из группы рыбьего жира без гистопатологических изменений, нормальной кости и остеоцита (Н \& E X 100).

ненасыщенных жирных кислот, эйкозапентаеновой кислоты (EPA) C20: 5n3 и докозагексаеновой кислоты (DHA) C22: $6 \mathrm{n3}$, в то время как соевое масло содержало наибольшее количество $\omega-6$ полиненасыщенных жирных кислот (Линолевая кислота) C18: 2n6. С другой стороны, основными полиненасыщенными жирными кислотами, обнаруженными в льняном масле, была а-линоленовая кислота (ALA) C18: 3n3. Как видно из результатов этого исследования, состав жирных кислот соевого масла, льняного масла и рыбьего жира отличается друг от друга и имеет множество различных жирных кислот, поэтому необходимо было оценить, какое масло является более эффективным в метаболизме костей и в профилактике остеопороза.

\section{Биомаркеры, связанные с воспалением и окислительным стрессом}

Группа с преднизолоном зафиксировала самые высокие значения маркеров воспалительного и окислительного стресса ФНО-а и МДА соответственно, в то время как контрольная группа зафиксировала самые низкие значения (рис. 2,3). С другой стороны, введение масел значительно улучшило эти показатели в группах, особенно рыбьего жира, который продемонстрировал нормальное значение МДА по сравнению с контрольной группой.

Результаты гистологических исследований бедренной кости на фоне использования рыбьего жира, соевого масла, льняного масла

Результаты гистологических исследований бедренной кости показали, что контрольная группа (рис. 4A) и группа рыбьего жира (рис. 4Е) имели нормальную толщину кортикальной кости и остеоцит без гистопатологических изменений. В противоположность этому, в группе преднизолона (рис. 4В) четко показана тонкая кортикальная кость с наличием трещин, аномальных остеоцитов и нескольких полостей резорбции внутри матрикса. С другой стороны, только несколько трещин в кортикальной кости были замечены в группе соевого масла (рис. 4С), в то время как был некоторый очаговый некроз с небольшим количеством трещин в кортикальной кости крыс из группы льняного масла (рис. 4D). 


\section{3. ОбсужАение}

в нашем исследовании установлено, что состав жирной кислоты льняного масла представлен а-линоленовой кислотой (ALA) $\omega$-3 ПНЖK, мононенасыщенной олеиновой кислотой.

Кроме того, основной жирной кислоты, содержащей-

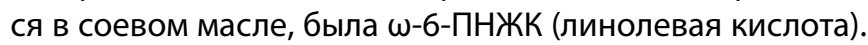
Этот результат был аналогичен работе Dorni et al., [9] которые обнаружили, что анализ жирных кислот соевого масла показал, что полиненасыщенная линолевая кислота $\omega-6$ была самой высокой (более 50\%), за ней следовали мононенасыщенная олеиновая кислота, а затем насыщенная пальмитиновая кислота, составляющая почти более 90\% всех жирных кислот. С другой стороны, известно, что подсолнечное масло богато линолевой и олеиновой кислотами. Сообщалось, что рыбий жир является хорошим источником длинноцепочечных $\omega$-3 ПНЖК со значительными количествами EPA и DHA, которые считаются метаболически активными соединениями [10].

Глюкокортикоиды (ГК) поглощаются через клеточную мембрану специальными рецепторами и влияют на метаболизм липидов, белков и углеводов. Воздействие ГК на кость может быть связано с дисбалансом между резорбцией кости и ремоделированием кости [11].

МДА является вторичным веществом перекисного окисления липидов, которое тесно связано с окислительным стрессом. По нашим данным, лечение маслами значительно снижало окислительный стресс во всех группах. Han, Parker [12] обнаружили, что добавление льняного масла значительно снижало уровни МДА в сыворотке и печени и подавляло печеночный окислительный стресс. Сообщалось об иммунологическом действии соевого масла и его влиянии на улучшение провоспалительного статуса и окислительного стресса. Согласно данным, полученным Muga, Chao [13], обработка рыбьим жиром снижала уровень перекисного окисления липидов до уровня, равного или ниже контрольного уровня, и это может предотвращать или лечить перекисное окисление липидов. Pipingas et al., [14] изучали влияние рыбьего жира на здоровье у 160 здоровых людей, и исследование показало, что ежедневное потребление рыбьего жира предотвращает окислительный стресс. Остеоциты могут модулировать образование и функцию, как остеобластов, так и остеокластов. Апоптотические остеоциты высвобождают некоторые провоспалительные цитокины, такие как ФНО-а, чтобы стимулировать остеокластогенез.

Воздействие ГК может привести к апоптозу остеоцитов, вызывающему потерю костной массы. Наши данные показали, что в группе преднизолона зафиксированы высокие значения маркера воспаления ФНО-а. Апоптотические остеоциты, которые индуцируются после введения с помощью GC, могут усиливать образование ФНО-а. Согласно результатам наших исследований, лечение маслами, богатыми ПНЖК, уменьшило воспаление. Недавние исследования показали, что прием ПНЖК эффективно снижает маркеры воспаления. Muga, Chao [13] сообщили, что лечение рыбьим жиром регулирует воспаление путем снижения концентрации ФНО-а.

Наше гистологическое исследование костей показало, что преднизолон воздействовал на кости на клеточном уровне и вызывал многие нарушения в коре и остеоцитах, в то время как введение масел, особенно рыбьего жира, уменьшало большинство этих побочных эффектов преднизолона. Согласно Kasem et al., [15], гистологическое исследование бедренной кости крысы после введения преднизолона для индукции остеопороза показало значительное уменьшение толщины коры и количества остеоцитов в группе остеопороза по сравнению с контрольной группой. Derakhshanian et al., [16] зафиксировали уменьшение толщины коры и трабекулы, а также значительное уменьшение количества остеобластов у крыс, получавших глюкокортикоиды. ПНЖК могут подавлять действие остеокластов и усиливать активность остеобластов. Таким образом, резорбция кости ингибируется и стимулируется формирование кости. При добавление рыбьего жира улучшается МПК, механические и гистологические характеристики костей.

\section{Зак^ючение}

Результаты наших исследований показали, что в группе преднизолона зафиксированы высокие значения маркера воспаления ФНО-а. Апоптотические остеоциты, которые индуцируются после введения с помощью GC, могут усиливать образование ФНО-а.

Добавление в корм диетических масел, содержащих полиненасыщенные жирные кислоты омега-3, таких как рыбий жир, соевое масло и льняное масло, может снизить эффект преднизолона в развития остеопороза у крыс. Таким образом, изученные масла (соевое, льняное масла и рыбий жир), в частности, могут быть использованы в качестве естественных добавок для предотвращения потери костной массы.

\section{Б^агоАарности}

Работа выполнена за счет средств субсидии, выделенной в рамках государственной поддержки Казанского (Приволжского) федерального университета в целях повышения его конкурентоспособности среди ведущих мировых научно-образовательных центров. 


\section{ЛИТЕРАТУРА}

1. El Wakf A. M. Osteoprotective effect of soybean and sesame oils in ovariectomized rats via estrogen-like mechanism / A. M. El Wakf, H. A. Hassan, N.S. Gharib // Cytotechnology - 2014. - Vol. 66-N. 2-P. 335-343.

2. Jamilian M. The effects of omega-3 fatty acids from flaxseed oil on genetic and metabolic profiles in patients with gestational diabetes mellitus: a randomized, double-blind, placebo-controlled trial / M. Jamilian, Z. Tabassi, Ž. Reiner, I. Panahandeh, F. Naderi, E. Aghadavood, E. Amirani, M. Taghizadeh, R. Shafabakhsh, M. Satari // Br. J. Nutr. - 2020.-P. 1-26.

3. Ivanovs K. Extraction of fish oil using green extraction methods: A short review / K. Ivanovs, D. Blumberga // Energy Procedia — 2017. — Vol. 128 — P. 477-483.

4. Cao J.J. Increasing Dietary Fish Oil Reduces Adiposity and Mitigates Bone Deterioration in Growing C57BL/6 Mice Fed a High-Fat Diet / J.J. Cao, B. R. Gregoire, K. G. Michelsen, M. J. Picklo // J. Nutr. - 2020. - Vol. 150 - N. 1 - P. 99-107.

5. AOCS. 2009. Official Methods and Recommended Practices of the American Oil Chemists' Society, AOCS, Champaign, IL.

6. Veronezi C. M. Basil (Ocimum Basilicum L.) as a Natural A ntioxidant / C. M. Veronezi, T. Costa, N. Jorge // J. food Process. Preserv. — 2014. — Vol. 38 - N. 1 P. 255-261.

7. Draper H. H. Malondialdehyde determination as index of lipid Peroxidation / H. H. Draper, M. Hadley // In Methods in enzymology. — 1990 Vol. 186 - P. 421-431.

8. Kim T. ATP6v0d2 deficiency increases bone mass, but does not influence ovariectomy-induced bone loss / T. Kim, H. Ha, N. Kim, E.-S. Park, J. Rho, E. C. Kim, J. Lorenzo, Y. Choi, S. H. Lee // Biochem. Biophys. Res. Commun. — 2010. — Vol. 403 - N. 1 - P. 73-78.

9. Dorni C. Fatty acid profile of edible oils and fats consumed in India / C. Dorni, P. Sharma, G. Saikia, T. Longvah // Food Chem. — 2018. — Vol. 238 - P. 9-15.

10. Calder P.C. Marine omega-3 fatty acids and inflammatory processes: effects, mechanisms and clinical relevance / P. C. Calder // Biochim. Biophys. Acta (BBA)Molecular Cell Biol. Lipids - 2015.—Vol. 1851 - N. 4 - P. 469-484.

11. Lane N. E. Glucocorticoid-induced osteoporosis: new insights into the pathophysiology and treatments / N. E. Lane // Curr. Osteoporos. Rep.— 2019._ Vol. 17 — N. 1-P. 1-7.

12. Han X. Essential oils diversely modulate genome-wide gene expression in human dermal fibroblasts / X. Han, T. L. Parker // Cogent Med. — 2017.— Vol. 4 — N. 1 -P. 1307591.

13. Muga M. A. Effects of fish oil and spirulina on oxidative stress and inflammation in hypercholesterolemic hamsters / M. A. Muga, J. C. J. Chao // BMC Complement. Altern. Med. - 2014. - Vol. 14-N. 1-P. 470.

14. Pipingas A. Fish oil and multivitamin supplementation reduces oxidative stress but not inflammation in healthy older adults: a randomised controlled trial / A. Pipingas, A. Sinclair, K. D. Croft, A. S. Januszewski, A. J. Jenkins, T. A. Mori, R. Cockerell, N. A. Grima, C. Stough, A. Scholey // J. Funct. Foods - 2015.-Vol. 19P. 949-957.

15. Kasem M. A. Histological effect of bisphosphonate, vitamin D and olive oil on glucocorticoid induced osteoporosis (Gio) in Albino Rat / M. A. Kasem, A. M. AbdelAleem, A. S. Said, E.-S. G. Khedr // Egypt. J. Hosp. Med. — 2016. — Vol. 65 — N. 1 — P. 699-708.

16. Derakhshanian H. Quercetin prevents experimental glucocorticoid-induced osteoporosis: a comparative study with alendronate / H. Derakhshanian, M. Djalali, A. Djazayery, K. Nourijelyani, S. Ghadbeigi, H. Pishva, A. Saedisomeolia, A. Bahremand, A. R. Dehpour // Can. J. Physiol. Pharmacol.— 2013.—Vol. 91 - N. 5 P. 380-385.

(с) Элбахнасави Амр Самир (amrsamir84@yahoo.com ), Валеева Эмилия Рамзиевна (val_med@mail.ru).

Журнал «Современная наука: актуальные проблемы теории и практики» 